\title{
Entre a hybris e a ápolis: Proximidades entre Rosa e Chico Buarque
}

\author{
Maria do Rosário Figueiredo ${ }^{1}$
}

RESUMO: No presente ensaio, compara-se o conto rosiano "A Benfazeja" com a canção "Geni e o Zepelim", de Chico Buarque de Hollanda,, considerando, em ambos, o processo de construção textual em uma perspectiva do trágico.

ABSTRACT: This essay aims to compare short story "A Benfazeja", by Guimarães Rosa, to the song "Geni e o Zepelim", by Chico Buarque de Hollanda, by considering in both of them the textual building process in a tragic perspective.

PALAVRAS-CHAVE: Guimarães Rosa, Chico Buarque, literatura; canção; trágico.

KEYWORDS: Guimarães Rosa, Chico Buarque, literature; song, tragic.

A descoberta de Guimarães Rosa por Chico Buarque está, de certa forma, ligada à sua própria descoberta da literatura brasileira, quando, por volta dos 18 anos, ao deixar um pouco de lado os clássicos franceses, indicados pelo pai, passou a ler os autores brasileiros e diz ter se apaixonado pelo escritor de Cordisburgo, desejando, por muito tempo, escrever como ele. Segundo o próprio $\mathrm{Chico}^{2}$, o uso de neologismos, à maneira de Rosa, esteve muito presente em contos que escrevera e com os quais participou de alguns concursos.

Mas seriam os neologismos a única vertente de diálogo entre os dois autores? E o que dizer da musicalidade em que parece repousar a

\footnotetext{
${ }^{1}$ Mestranda em Literaturas de Língua Portuguesa. Pontifícia Universidade Católica de Minas Gerais (PUC-Minas). E-mail: zarafigueiredo@gmail.com

2 Conforme disse Chico Buarque, em entrevista a Augusto Massi, transcrita por Rinaldo de Fernandes "E comecei ler o que não havia lido até então, de Mário de Andrade, Oswald de Andrade até Guimarães Rosa, por quem me apaixonei. Guimarães Rosa talvez seja esse marco para mim. Foi uma descoberta. Durante um bom tempo, queria escrever como Guimarães Rosa.Participei de diversos concursos de contos naquela época, textos cheios de neologismos.” (2004,p.26)
} 
criação literária de ambos, já apontada por estudos de Miguel Wisnik? ${ }^{3}$ Pois bem, uma revisita a algumas canções de Chico Buarque autorizanos a falar em outros elementos de confluência.

Em 1979, Chico Buarque lança o álbum "Ópera do Malandro”, no qual encontramos “Geni”, personagem da canção "Geni e o Zepelim" que em muito nos lembra a figura da "Mula-marmela", personagem do conto “A Benfazeja”, de Primeiras estórias4, livro lançado em 1961, já que ambos parecem inscritos na ordem do trágico, numa abordagem que privilegie o culto do deus grego da metamorfose Dioniso.

$\mathrm{Na}$ narrativa de Rosa, temos a estória da "Mula-Marmela", uma "mulher malandraja, a malacafar", (p. 109) que "andava meio se agachando; com os joelhos para adiante” (p.109), uma mulher que tinha “o andar em ponta, em sestro de égua solitária”. Tal mulher é guia de um cego, seu enteado "Retrupé”, filho do finado "Mumbungo", marido dela. No lugarejo onde moram, as pessoas os recriminam, não só ao pai, "hediondo, o cão de homem, calamidade horribilíssima", mas, também, aquele "Retrupé", que era "o filho-tal-pai-tal; o cão na prática verdade" (p.109) e ela, a "Mula-Marmela".

Os habitantes do povoado não "atentam na mulher, nem fosse possivel”, já que "a gente não revê os que não valem a pena” (p. 109). Um dia, a "Mula-Marmela" mata o marido e, algum tempo depois, morre também "Retrupé". A acusação, pela cegueira e morte do enteado recai sobre ela. Seus concidadãos "não só a acusaram e prenderam, porque maior era o alívio de a ver partir, para nunca", "sem lhe oferecer ao menos qualquer espontânea esmola” (p. 117). E assim, expulsaram-na, "a viram partir: o que figurava a expedição do bode — seu expiar", (p.117), mas, antes de sair, ela avista

aquele um cachorro morto, abandonado meio já podre, na aponta da rua e pegou-o às costas, o foi levando-: se para livrar o

\footnotetext{
${ }^{3}$ http://www1.folha.uol.com.br/folha/ilustrada/ult90u45707.shtml

4 Todas as citações de Primeiras estórias são da edição de 1977. ROSA, João Guimarães. Primeiras estórias. Rio de Janeiro:Livraria José Olympio Editora, 1977.
} 
logradouro e lugar de sua pestilência perigosa, se para piedade de dar-lhe cova em terra, se para com ele ter com quem ou o que se abraçar na hora de sua grande morte solitária”.

( p.118)

Por sua vez, "Geni", na canção de Chico Buarque, apresenta, desde menina, uma vida desregrada do ponto de vista da ordem cívica estabelecida. Ela "dá pra qualquer um”, o seu corpo é de todos os desvalidos: cegos, retirantes, viúvas, detentos, velhos, crianças de internato. Toda a galeria de marginalizados a possui, no "mangue", no "cais do porto", no "mato", em qualquer lugar, enfim.

Esse comportamento de "Geni" que, ao se entregar a todos, devolve alguma vida aos desvalidos, é usado, contra ela, pelos habitantes da mesma cidade, lembrando-lhe, sempre, da condição de maldita.

O que as pessoas do povoado não imaginavam era que este lugar estava à beira da destruição devido aos "horrores e iniqüidades" que certo comandante presenciara ali, e a única forma de salvar a cidade seria atender-lhe o desejo de ser "servido", àquela noite, por uma formosa dama: "Geni”.

Outro detalhe que a cidade desconhecia (afinal, como nos lembra o narrador rosiano, quando se vive perto demais não se revê aqueles que não valem a pena) é que "Geni" tinha suas preferências, e, a deitarse com "homem tão nobre", "preferia amar com os bichos". A recusa, considerada, pela cidade, uma heresia, levou a todos a clamar, em coro, pela ajuda de Geni, que, diante do apelo coletivo, domina seu asco e se entrega ao forasteiro que se "lambuza" durante toda uma noite "lancinante". Tão logo amanhece, a cidade, já redimida pelo "sacrifício" a que "Geni" fora submetida, em cantoria, volta a lembrar-lhe a estirpe maldita.

Ao aproximarmos os dois textos, percebemos semelhanças bastante significativas no que diz respeito, primeiro, ao comportamento das personagens em relação à ordem cívica, nas sociedades onde estão inseridas. 
Tanto a "Mula Marmela" quanto "Geni", ao deixarem prevalecer a vontade em detrimento da ordem instituída, transgridem os limites impostos pela sociedade, essa se entregando a todos, numa sexualidade excessiva, aquela matando o marido e o enteado. Ambas, agindo assim, são levadas à ultrapassagem da "medida", à transgressão do que é justo e direito, isto é, à hybris, ${ }^{5}$ qualidade que leva o homem a entrar em conflito com outro homem ou com os deuses, ou com outras forças superiores, possibilitando o acontecer trágico.

A manifestação do trágico estaria ligada, assim, de forma inexorável, à vontade e à superação humana que se daria através do êxtase, do entusiasmo, vocábulo cuja etimologia já nos aponta para um mergulho em Deus, en-theos, no caso, no deus Dioniso.

Ao tratar do deus do êxtase e do entusiasmo, Junito Brandão6 esclarece que quando o homem sai de si mesmo, pelo êxtase e entusiasmo, sente-se imortal, deixando de ser um antropos para ser um herói. E é exatamente pela possibilidade de superação e liberdade conquistada que as mulheres, principalmente elas, eram as maiores adeptas de Dioniso, o que nos permite filiar a "Mula-Marmela" e "Geni" à tradição grega do dionisismo.

Tanto em Rosa quanto em Chico Buarque, defrontamo-nos com uma legião de desvalidos - assassinos, mendigos, errantes, detentos, lazarentos, velhos, doentes, viúvas - que fazem vacilar a ordem estabelecida. E é nesta galeria de desvalidos que a figura feminina surge, vinculando-se ao tema da marginalidade, e estamos, de novo, às voltas com o dionisismo: porque ele "é antes de tudo e privilegiadamente, um assunto de mulheres”, escreve Vernant, citado

5 O conceito de hybris é, aqui, tomado de Johnny Mafra. MAFRA, J. J. Hýbris: a essência da tragédia. Belo Horizonte, 1990. (edição provis.).

${ }^{6}$ BRANDÃO, Junito de Souza. Mitologia grega I. Petrópolis: Editoras Vozes, 2001. 
por Meneses ${ }^{7}$ e, também, porque a transformação operada no homus dionysiacus, pelo êxtase e entusiasmo, levava ao rompimento da ordem social, política e religiosa, era uma ameaça à polis aristocrática , ao status quo vigente.

Na canção de Chico Buarque, ainda que seja a sua condição de prostituta, e, como tal, excluída, que permitirá a "Geni" redimir a cidade; o fato de ela "dar pra qualquer um", em qualquer lugar, desestabiliza a ordem cívica da cidade, e isso, a torna "maldita", um miasma, uma mancha que deve ser expiada.

No conto rosiano, a "Mula-marmela", pela sua desmedida, mata o marido e o enteado à guisa de livrar o vilarejo de ambos; agindo assim, matando para purificar o povoado de um miasma, alcança um lugar acima do homem, supera sua condição. Ao fazê-la, ultrapassa a sua medida, desregra o curso normal da vida, torna-se ela mesma um miasma que deve ser expiado.

Note-se que, nos dois casos, encontramos a figura do feminino como elemento desestabilizador da ordem cívica, social e religiosa da pólis; uma por ter um comportamento sexual e erótico desviado pela bissexualidade, a outra por ser esposa e assassina do marido, além de madrasta daquele "de outra raça, vindo do "horroroso informe" ( p.115). As duas, e logo elas, "tão coitadas e singelas”, a partir da superação do seu "não lugar", livram, paradoxalmente, seu lugar do horror e destruição; mas salvando a polis, encarnam a figura do phármakos e são lançadas fora da coletividade, o que figura "a expedição do bode seu expiar" (Rosa, 1977, p. 117).

Ainda sob o signo do trágico, outro elemento que parece aproximar os dois textos é aquele relacionado à voz narrativa. A

7 MENESES, Adélia Bezerra de. “O 'eterno feminino’:modulações”. In: Literatura e Sociedade 2. São Paulo: Departamento de Teoria Literária e Literatura Comparada da Universidade de São Paulo, 1997, p. 170-185. 
estratégia pela qual o sujeito lírico, em $\mathrm{Chico}^{8}$, e o narrador, em Rosa dão voz ao "feminino" sugere uma recriação da figura do coro grego clássico, na sua função não só de exprimir, em temores e esperanças, os sentimentos dos espectadores que compunham a comunidade cívica, mas, também, comentar e refletir sobre a relação "entre o individuo e as forças cósmicas", no dizer de Anatol Rosenfeld. ${ }^{9}$

Em "A Benfazeja”, temos um narrador de $3^{a}$ pessoa, onisciente, mas com uma onisciência especial. É ele, o narrador, quem efetiva, no conto, a forte reflexão sobre a identidade das personagens, seus destinos e sua sorte:

Se eu disser o que sei e pensam, vocês inquietos se desgostarão. Nem consintam, talvez, que eu explique, acabe. A mulher tinha de matar, tinha de cumprir por suas mãos o necessário bem de todos. Só ela mesma poderia ser a executora -da obra altíssima, que todos nem ousavam conceber, mas que, em seus escondidos corações, imploravam. (ROSA, 1977, p.112)

Mais do que narrar, ele intervém na ação narrada, e o faz solidariamente; tenta aproximar a personagem "Mula-Marmela" e seus “concidadãos". Tenta chamar "o povo" à razão, ainda que seja à razão do narrador, e fazê-lo ver aqueles que se escolheu ignorar:

Diz-se que ela teria lágrimas nos olhos; que falou, soturna de ternuras terríveis: - "Meu filho..." $\mathrm{E}$ olhou para uma banda, disse alguma coisa mais, como se falando ao outro; soluçava, também, pelo Mumbungo, seu reconduzido marido, por sua parte, de seu ato. Disso, vocês não quererão saber, são emdiabas confusões, disso vocês não sabem. E, se, para que? Se ninguém entende ninguém; e ninguém entenderá nada, jamais; esta é a prática verdade. (ROSA, 1977, p.117)

A onisciência do narrador faz-nos, também, pensar no comportamento dos atenienses frente à exibição das peças trágicas. Como seus temas vinham dos mitos, quando representados na hélade,

8 Está se tomando a canção, somente enquanto letra, texto poético; ciente, todavia, de que a separação implica uma perda, pois sabemos que a melodia e o arranjo são formas de significação.

9 ROSENFELD, Anatol. O teatro épico. São Paulo:Editora Perspectiva, 2000. 
já eram conhecidos dos cidadãos. Pois bem, o narrador rosiano mantém essa prática, adiantando, ao leitor, já no primeiro parágrafo do conto, certo número de informações acerca da personagem e da estória transcorrida:

Sei que não atentaram na mulher; nem fosse possível. Vive-se perto demais, num lugarejo, às sombras frouxas, a gente se afaz ao devagar das pessoas. A gente não revê os que não valem a pena. Acham ainda que não valia a pena? (ROSA, 1977, p.109) (grifos meus).

Nota-se, por essa transcrição, que, desde o início do conto, o final já é sabido pelo narrador, que se posiciona de um lugar do presente "acham ainda", interpelando um interlocutor o qual, a priori, não sabemos quem é: se nós, leitores ou os concidadãos da "MulaMarmela”, se teria valido a pena algo, ou seja, em relação ao passado.

$\mathrm{O}$ narrador enquanto medeia a relação entre a personagem e possiveis interlocutores, instaura no texto uma atmosfera ambígua, já que "pena", em "valer a pena" desliza entre um sentido e outro. Se de um lado, podemos compreendê-lo na acepção usual do termo, significando “o esforço compensou?”, por outro, ele se inscreve sob o signo do trágico, no qual "a pena” está ligada ao campo semântico da condenação e do castigo.

O narrador rosiano, ainda neste papel do coro, questiona, de forma irônica, a hipocrisia que julga haver por parte dos possiveis concidadãos, perguntando se não se vai, àquela altura, à procura do corpo morto, [da "Mula-marmela"] para, assim, enterrá-lo, "em festa e pranto": "Vocês, de seus decretantes corações, a expulsaram. Agora, não vão sair a procurar-lhe o corpo morto, para contritos, enterrá-lo, em festa e pranto, em preito?” (ROSA, 1977, p.117).

“Geni e o Zepelim" também é marcado por uma voz que intermedeia a relação da sua personagem e seus concidadãos para, em seguida, refletir nos leitores. O sujeito poético posiciona-se como voz que critica os valores religiosos e sociais que julgam e condenam a personagem Geni. 
A sua figura, esboçada pelo sujeito lírico, surge do meio de uma procissão de aflitos e marginalizados que a cercam e com os quais ela se funde, surge da confluência de vozes que a condenam, que cantam, em coro, sua marginalidade, definindo seu destino: "feita pra apanhar / boa de cuspir / Ela dá pra qualquer um / Maldita Geni”.

A mesma ironia que vimos em Rosa, quando o narrador inquire do povoado se iriam, àquela altura, em busca do corpo da "Mulamarmela" para dar-lhe "festa e pranto", efetiva-se na canção, quando o sujeito poético chama de "heresia" o fato de Geni recusar-se a deitar com o comandante do Zepelim: "Ao deitar com homem tão nobre / tão cheirando a brilho e a cobre / preferia amar com os bichos. Ao ouvir tal heresia, a cidade em romaria / foi beijar a sua mão".

Outro trecho que, também, merece ser mencionado pelo uso do mesmo recurso é aquele em que as grandes instituições da sociedade: igreja, governo e poder econômico, nas figuras do bispo de "olhos vermelhos", do prefeito "de joelhos" e do banqueiro "com um milhão" vêm suplicar a Geni que salve a cidade.

Neste momento, a ironia atinge seu ponto alto, pois Geni passa de maldita à bendita, segundo o jogo de conveniência dos representantes da cidade.

Se em "Geni e o Zepelim" temos um coro de vozes que julga e condena a personagem, por outro lado, o sujeito poético também pode ser entendido como uma voz coral, já que é ele quem efetiva a reflexão, pela ironia, entre Geni e os leitores.

Anatol Rosenfeld, ao tratar das funções atribuídas ao coro, destaca a presença do autor como uma das vozes que irrompe dali:

Através do coro parece manifestar-se, de algum modo, o "autor", interrompendo o diálogo dos personagens e a ação dramática, já que em geral não lhe cabem funções ativas, mas apenas contemplativas de comentário e reflexão. [...] Representante da polis - Cidade-Estado que é parte integral do universo - o coro medeia entre o indivíduo $\mathrm{e}$ as forças cósmicas, abrindo o organismo fechado da peça a um mundo mais amplo, em termos sociais e metafísicos. (ROSENFELD, 2.000, p.40) 
O oportuno comentário leva-nos a pensar na visão crítica destes dois autores: Guimarães Rosa e Chico Buarque que, recriando temas da literatura clássica, transpondo gêneros literários, usando de frestas como a voz coral, irrompem na crítica à uma sociedade que ainda deixa à margem todos os que estão "tão fora da vida exemplar de todos". Ambos deram, por meio da linguagem, em verso ou prosa, uma dimensão social à literatura.

\section{Referências bibliográficas}

BRANDÃO, Junito de Souza. Mitologia grega I. Petrópolis: Editora Vozes, 2001.

BRANDÃO, Junito de Souza. Mitologia grega III. Petrópolis: Editora Vozes, 2001.

CÂNDIDO, Antônio; GOMES, Paulo Emílio Salles; PRADO, Décio de Almeida; ROSENFELD, Anatol. A personagem de ficção. São Paulo: Editora Perspectiva, 2002.

FERNANDES, Rinaldo de. (Org.) Chico Buarque do Brasil.Rio de Janeiro:Editora Garamond LTDA, 2004.

MAFRA, J. J. Hýbris: a essência da tragédia. Belo Horizonte, 1990. (edição provis.).

MENESES, Adélia Bezerra de. Poesia de Política em Chico Buarque. São Paulo: Ateliê Editorial, 2002.

MENESES, Adélia Bezerra de. “O ‘eterno feminino':modulações”. In: Literatura e Sociedade 2. São Paulo: Departamento de Teoria Literária e Literatura Comparada da Universidade de São Paulo, 1997, p. 170-185.

ROSA, João Guimarães. Primeiras estórias. Rio de Janeiro: Editora José Olympio, 1977.

ROSENFELD, Anatol. O teatro épico. São Paulo: Editora Perspectiva, 2000.

VERNANT, Jean Pierre e VIDAL-NAQUET, Pierre. Mito e tragédia na Grécia antiga. São Paulo: Perspectiva, 2002.

BUARQUE, Chico. Perfil (disco), Universal Music, Rio de Janeiro [s.d]

WISNIK,Miguel. In: http://www1.folha.uol.com.br/folha/ilustrada/ult90u45707.shtml. Acesso em 25/02/2008. 